\title{
THE IMPACT OF OWNER PERCEPTIONS ON CORPORATE GOVERNANCE TOWARDS TAX COMPLIANCE OF SMES
}

\author{
Rosalita Rachma Agusti \\ Faculty of Administrative Science, Brawijaya University \\ rosalitarachma@ub.ac.id
}

\begin{abstract}
This research studies tax compliance behavior of SMEs business owners by observing perceptions of corporate governance principles that are appropriate for SMEs. The owner's perception of the importance of implementing the principles of corporate governance SMEs in the business is believed to provide a strong foundation for the business continuity of the SMEs. The study was conducted by conducting a survey of SMEs business owners in Malang City as a city that serves as a barometer of creative economic development. The survey was conducted by distributing questionnaires that use a Likert scale to measure perceptions of business actors. The results showed that SMEs owners' perceptions of the importance of implementing corporate governance principles including information and communication, external audit, internal control and stakeholders influence the perception of business actors on tax compliance.
\end{abstract}

Keywords: Corporate Governance, Tax Compliance, SMEs

\begin{abstract}
ABSTRAK
Penelitian ini mempelajari tentang perilaku kepatuhan pajak pemilik Industri Kecil Menengah (IKM) dengan mengamati persepsi tentang prinsip-prinsip tata kelola perusahaan yang sesuai untuk IKM. Persepsi pelaku usaha tentang pentingnya menerapkan prinsip-prinsip tata kelola perusahaan IKM dalam bisnis diyakini memberikan fondasi yang kuat untuk kelangsungan bisnis IKM. Penelitian dilakukan dengan melakukan survei terhadap pemilik usaha IKM di Kota Malang sebagai kota yang berfungsi sebagai barometer perkembangan ekonomi kreatif. Survei dilakukan dengan menyebarkan kuesioner yang menggunakan skala likert untuk mengukur persepsi pelaku bisnis. Hasil penelitian menunjukkan bahwa persepsi pemilik IKM tentang pentingnya menerapkan prinsip-prinsip tata kelola perusahaan termasuk informasi dan komunikasi, audit eksternal, pengendalian internal dan pemangku kepentingan mempengaruhi persepsi pelaku usaha tentang kepatuhan pajak.
\end{abstract}

Kata kunci: Tata kelola, kepatuhan perpajakan, Industri Kecil Menengah 


\section{A. INTRODUCTION}

The small and medium enterprises (SMEs) sector of Indonesia contributes $60 \%$ of Indonesian Economic reflected in Gross Domestic Product (GDP) and absorbs 97.02\% of the workforce in 2017 (Depkop, 2017). This indicates that with the development of SMEs, the country's economy will also grow. Therefore, SME is an important sector for the government to build a strong economy.

Good governance implemented by companies can improve the performance of these entities, including SMEs. The application of good governance will assist SMEs in carrying out robust business processes, and encourage future development and expansion plans as a form of business sustainability. Rajif (2012) states that the biggest problems of SMEs in Indonesia are market uncertainty, the sustainability of SMEs and unclear bookkeeping. The implementation of corporate governance for SMEs will provide a foundation for businesses to operate more transparently and accountably. Governance for SMEs is related to the decision making process, procedures and attitudes of business actors in the process of achieving company goals.

Several countries have developed good governance principles for SMEs, one of which is Dubai SMEs (2012). Dubai SMEs (2012) establishes 9 pillars of good governance for SMEs. The Dubai Government believes that the principles underlying the corporate governance codes reflect best practices and can be applied to SMEs based on their level of growth.

The application of the principles of Corporate Governance in SMEs is an interpretation of the understanding of business actors towards good business management. Compliance is a new era of corporate governance. Good business management will be followed by compliance in carrying out tax obligations as a form of good business management that is manifested in compliance with the government, among others, on tax regulations. This is because compliance is a new concept of corporate governance.

The compliance play an important roles by which assign the ability of the firm to adopt a legal behavior, regulations and also social norms. Compliance behavior does not fit with the corporate governance in tradisional approach because it does not come from the board of directors or federal securities law (Griffith, 2016). Related to the financial activities of the firm, compliance to the government regulations reflected in tax compliance. Therefore, this study aims to explore whether SMEs owner perception of corporate governance principles has an impact on SMEs tax compliance behavior.

\section{B. LITERATURE REVIEW}

\section{Agency Theory and Corporate Governance in SMEs}

Agency theory was introduced by Jensen and Meckling (1976). This theory is based on the relationship between principal and agent. This relationship is often referred to as an agency relationship. An agency relationship arises when a person or more (the principal) employs another person (agent) to do a job in accordance with the principal's interests. This has the potential to create conflicts of interest called agency conflicts. The conflict arises because in addition to achieving these goals, management has a tendency to take actions that are not consistent with the aim of increasing shareholder prosperity. Management often has different interests from these objectives. This triggers a conflict of interest between shareholders and management. Corporate governance is believed to minimize agency conflict through developing good corporate governance principles. However, research on the role of corporate governance in many companies is carried out in large companies.

Clarke (2006) revealed that corporate governance mechanism is not only related with large companies but also SMEs. Dubai (2011) developed 9 key pillars of SMEs corporate governance. This study adopt 9 pillars: formal governance framework, management succession, information and communication, board of commisisioners/advisors, board/advisors' performance, external audit, internal control, stakeholders, and family governance to measure the SMEs owner perception of corporate governance.

\section{Hard to Tax Sector}

The concept of tax compliance includes the existence of hard to tax (HTT) sectors identified as small-and-medium-sized firms, professionals and farmers as revealed by Musgrave (1981) on Alm. Et. (2004). Although HTT reflects the efficacy of the tax system, Bahl (2004) stated that there is no precise 
definition about it. Further, Bahl (2004) describes HTT sector as "those parts of the population and those that are not easily reached by the assessment and collection system".

\section{Hypothesis Development}

Based on agency theory, agency conflict can be minimized through the implementation of corporate governance principles in the company. Good corporate management based on corporate governance principles in a modern approach is reflected in corporate compliance, including compliance with government regulations, one of which is taxation regulations.

Disruptive technology and innovations (DTI) brings a revoluted comprehensive paradigm into corporate governance. Brennan, et.al (2019) revealed that governance ecosystem involve internal accountability mechanisms, accounting mechanisms and external accountability mechanism. The key attributes of corporate governance future challenges related to the DTI are related with the capacity: agile and collaborative governance; and structural: decentralised and distributed governance. Internal and external corporate governance have the ability to explain tax avoidance in form of tax management, tax planning, tax aggressiveness, tax sheltering or tax evasion (Kovermann and Velte, 2019).

Corporate governance not only essentials to be implemented by large companies but also SMEs (Clarke, 2006). The 9 principles of corporate governance in accordance with the characteristics of SMEs has been developed by Dubai SMEs (2011). Therefore, the hypothesis of this research are SMEs' owner perception of corporate governance determines company's tax compliance.

\section{RESEARCH METHOD}

This study aims to find out the impact of corporate governance on tax compliance in SMEs. This research is classified as an explanatory research to find out the relationship between the independent variables, namely the Perception of Corporate Governance to Tax Compliance as the dependent variable. The data used in this study are primary data that is data obtained directly through a survey of research objects, namely SMEs business actors. Population of this study is the business owner who selected by non-probability sampling with a purposive approach based on the criteria of students who own a business and 57 respondents are collected. Primary data used in the form of a questionnaire. The research instrument was developed based on the 9 pillars of SMEs corporate governance (Dubai SMEs, 2011). Research questionnaire was developed using a Likert scale which provides 5 alternative answers. Data were analyzed using multiple linear regression methods.

D. Analysis and Discussion

1. Characteristics of Respondents

\section{a. Educational Background}

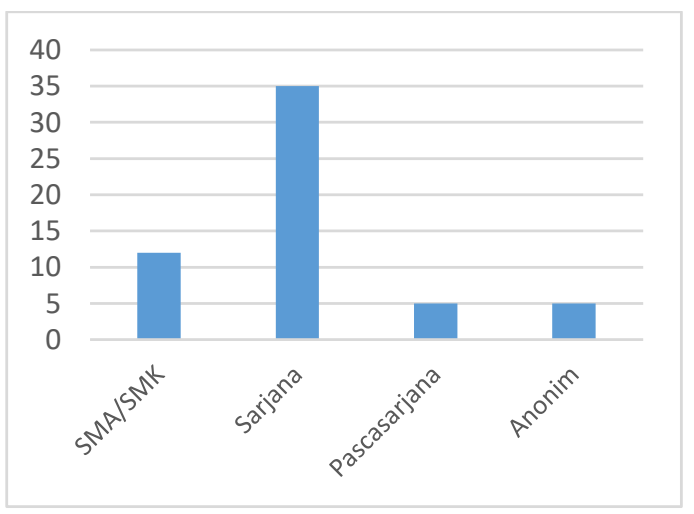

Figure 1. Characteristics Respondents by Educational Background

Based on the diagram above it can be seen that respondents who have the last education level of SMA / SMK are as many as 12 people or around $21.05 \%$, respondents who have the last education level are 35 people or around $61.4 \%$, respondents who have the last education level postgraduate program is 5 people or around $8.77 \%$ while respondents who did not give their last education level are 5 people or around $8.77 \%$. 
b. Age



Figure 2. Characteristics Respondents by Age

Based on the diagram above it can be seen that respondents who have an age between 20-35 years are 54 people or around $94.74 \%$, respondents aged between 36-50 are as many as 2 people or around $3.51 \%$ while respondents who have age above 50 years is as much as 1 person or around $1.75 \%$.

\section{c. Business Age}

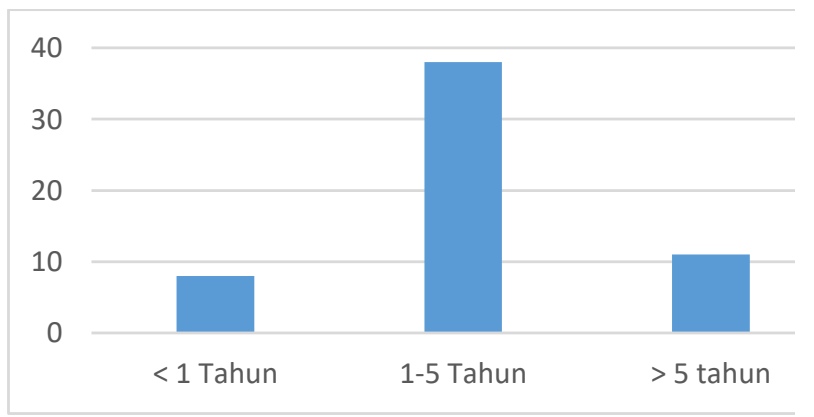

Figure 3. Characteristics Respondents by Business Age

Based on the diagram above it can be seen that respondents who have been in business $<1$ year are 8 people or around $14.03 \%$, respondents who have been in business for 1 to 5 years are as many as 38 people or around $66.67 \%$ while respondents who have running a business $>5$ years is as many as 11 people or around $19.3 \%$.

\section{d. Business Product}

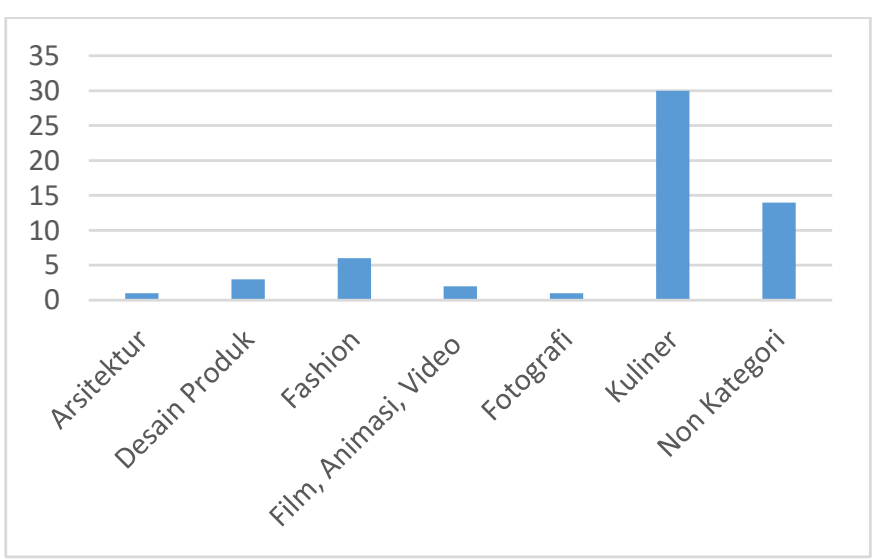

Figure 4. Characteristics Respondents by Business Product

Based on the diagram above it can be seen that respondents who have an architectural type of business are as many as 1 person or around $1.75 \%$, respondents who have a type of product design business are as many as 3 people or around $5.26 \%$ while respondents who have a type of fashion business are as many as 6 people or about $10.53 \%$, respondents who have the type of film, animation, video business are as many as 2 people or around $3.51 \%$, respondents who have a type of photography business are as many as 1 person or about $1.75 \%$, respondents who have the type culinary businesses are as many as 30 people or around $52.63 \%$ while respondents who have non-category business types based on 16 creative economic businesses according to Bekraf are as many as 14 people or around $24.56 \%$.

Tabel 1. Hypothesis Test

\begin{tabular}{|l|l|l|c|}
\hline Variable & \multicolumn{1}{|c|}{$\begin{array}{c}\text { Corporate } \\
\text { Governance Codes }\end{array}$} & Coefficients & Sig. \\
\hline X1 & $\begin{array}{l}\text { Formal Governance } \\
\text { Framework }\end{array}$ & $-0,521$ & 0,605 \\
\hline X2 & $\begin{array}{l}\text { Management } \\
\text { Succession }\end{array}$ & 1,372 & 0,176 \\
\hline X3 & $\begin{array}{l}\text { Information and } \\
\text { Communication }\end{array}$ & 2,353 & 0,023 \\
\hline X4 & $\begin{array}{l}\text { Board of } \\
\text { Commisioners/Advisors }\end{array}$ & $-0,546$ & 0,588 \\
\hline X5 & $\begin{array}{l}\text { Board of Advisors' } \\
\text { Performance }\end{array}$ & $-1,662$ & 0,103 \\
\hline X6 & External Audit & $-1,700$ & 0,096 \\
\hline X7 & Internal Control & 2,166 & 0,035 \\
\hline X8 & Stakeholders & 2,162 & 0,036 \\
\hline X9 & Family Governance & 1,352 & 0,158 \\
\hline
\end{tabular}


The analysis shows that at a significance level of $1 \%$, the perception of business operators on information for shareholders has a significant influence on tax compliance of 2.353. This shows that business operators' perceptions of information conveyed to shareholders determine tax obligations that are fulfilled by SMEs. SMEs perceptions of credible books of account that provided by audited financial report affect tax compliance. This shows that tax compliance implemented by SMEs is also determined by the perception of business actors on the importance of credible books of account. SMEs' perceptions of the internal control framework and recognizing the needs of stakeholders influence tax compliance. This shows that the perception of business actors on the internal control framework affects tax compliance implemented by business actors. In addition, the perception of business actors about the importance of recognizing the needs of stakeholders determines the level of tax compliance of a business.

\section{E. CONCLUSION AND SUGGESTION Conclusion}

The majority of respondents in this study are productive age in the culinary business. Perceptions of business actors that determine tax compliance include registration, payment and reporting are perceptions of business actors on the importance of information to equity owners, credible books of accounts, internal control framework and ability to recognize the needs of stakeholders.

\section{Suggetion}

For further research, it can be considered to conduct study using other corporate governance principles in accordance with SMEs to see the role of corporate governance for the success of SMEs.

\section{F. REFERENCES}

Alm, James; Jorge Martinez-Vasquez and Sally Wallace. 2004. Taxing the Hard to Tax. Elsevier

Bahl, Roy. 2004. Reaching the Hardest to Tax: Consequences and Possibilities. Elsevier, pp 338-354
Balakrishnan, Karhtik, Jennifer Blouin, Wayne Guay. 2011. Does Tax Aggressiveness Reduce Financial Reporting Transparency? University of Pennsylvania

Brennan, Niamh M., Nava Subramaniam, Chris J. Van Staden. 2019. Corporate Governance Implications of Disruptive Technology: An Overview. The British Accounting Review 51 (2019) pp 1-15

Kovermann, Jost, Patrick Velte. 2019. The Impact of Corporate Governance on Corporate Tax Avoidance - A Literature Review. Journal of International Accounting, Auditing and Taxation 36 (2019) pp 1-29

Clarke, AD. 2006. SMEs and Corporate Governance: Politics, Resource and Trickle-Down Effects. University of Queensland

Devos, Ken. 2014. Factors Influencing Individual Taxpayer Compliance Behavior. Springer

Dubai SME. 2011. The Corporate Governance Code For Small and Medium Enterprises. Dubai

Ghozali, Imam. 2007. Aplikasi Analisis Multivariate dengan Program SPSS. Semarang: Badan Penerbit-Undip

Griffith, Sean J. 2016. Corporate Governance in an Era of Compliance. 57 Wm. \& Mary 2075

Inasius, Fany. 2018. Factors Influencing SME Tax Compliance: Evidence from Indonesia. International Journal of Public Administration

Pricewaterhouse Coopers. 2005. Corporate Governance Toolkit for small and medium enterprises. Australia 